\title{
男女体育専攻生の somatotype
}

—Sheldonのtrunk index法とHeath-Carterのanthropometry法による——

横山 泰行 (富山大学教育学部保健体育科)

（昭和57年 5 月 6 日 受付）

A study on somatotype of the male and female physical education majors

-relationship between the Sheldon's trunk index and

Heath-Carter's anthropometric methods-

Yasuyuki Yokoyama ${ }^{1}$

\begin{abstract}
To investigate the somatotype in the male and female physical education majors, the Sheldon's Trunk Index and Heath-Carter's Anthropometric Methods were applied to 25 male and 24 female college students. Comparisons of the trunk index and anthropometric methods of assessing physique types were made in the rating scores of the somatotype components. The results obtained were as follows:

1) The means of the three somatotype components (endomorphy, mesomorphy and ectomorphy) as assessed by the trunk index and anthropometric techniques for the male subjects were 2.8$4.9-2.9$ and $2.4-5.0-3.1$.

2) The means of the three somatotype components as assessed by the two methods for the female subjects were $3.6-4.7-2.5$ and $4.5-4.5-2.0$.

3) The differences between the means for the endomorphic, mesomorphic and ectomorphic components as assessed by the two methods in the male subjects were not significant by application of the $t$ ratio.

4) The difference between the endomorphic means as assessed by the two methods was significant at the 0.01 level in the female subjects. The higher mean was obtained by the anthropometric method. The mesomorphic and ectomorphic means were not significant between the two methods.

5) The correlations between the trunk index and anthropometric methods for the three somatotype components at two sexes were significant beyond the 0.05 level or the 0.01 level.

6) The endomorphy, mesomorphy and ectomorphy correlation coefficients between the two methods were $0.514,0.446,0.891$ in the male subjects and $0.622,0.554,0.817$ in the female
\end{abstract}

1 Department of Health and Physical Education, Faculty of Education, Toyama University, Toyamashi, Toyama (930) 
subjects.

7) The distributions of the male physical education majors into Primary Endomorph, Mesomorph, Ectomorph, Endomesomorphy and Mid-type on the basis of the trunk index and anthropometric assessments were $0-16-1-0-8$ and $0-14-1-1-9$. The distributions of the female physical ndncation majors were $3-10-0-1-10$ and $4-5-0-5-10$.

(Yasuyuki Yokoyama, "A study on somatotype of the male and female physical education majors-relationship between the Sheldon's trunk index and Heath-Carters, anthropometric methods-,"Jap. J. phys. Educ. 27-2:111-22, September, 1982)

\section{鍺言}

休格は祝觉によって判別できる関保上，古来よ りさまざまな体型に分類されてきている。医旺と 呼ばれる古代ギリシャの医師, Hippocrates は体 型を㸃灌体型と卒中体型11に二分している。前者 は肺結核に䍜りやすい体型であり，「体が細辰く， 项も長く，色白く頓に潮紅があり，胸は㹟く， 筋，脂肪の発育の墨いもの11)」である。啳者は脳 卒中に羅りやすい体型であり，「ズングリして肥 满し，项が短く，赤ら顔で，佰と胸が幅広く，筋 の発育もよいもの11)」である。

ドイッの精神科医であった Kretschmer 9) は 1921年に体格と性格に関する著書を公表してい る。その著書の中で，体格を肥満体型，闘士体 型, 無力性体型に 3 分類している。アメリカの医 師 Sheldonは1934年から 2 年間，体型と精神医学 の研究のためヨーロッパに留学した。この期間中 にKretschmer と接触を持って，体型矿究に多大 な影䒜を受けている。なお、シカゴ大学在籍中に は指尊教官であった Thurstone, L.L.からデータ 解析に必要な最新の統計的手法をマスターしてい る。

両者と人類学者であった Hooton,E.A. らに啓 哞されて, Sheldon ${ }^{14)}$ は1940年に体格分類の䂥究 法に科学的な手法を導入して，画期的な体格類型 法を確立した。彼は共同研究者であった Stevens と Tucker とともに，身体フォームの分類法を somatotyping と命名し，3つからなる基本成分の 概念を提示している。基本成分の名称は発生学的 にみて，3層からなる阫芽層に因んで名付けられ たものである。

(1) 内胚葉型（第 1 成分）：内肧葉層加発生
し，消化器系統の発達がよい体型である。腹部や 胸部は柔らかくて，丸みをおび，幅広くて大き い。頸や脚は太くて短い。

(2) 中肧葉型（第 2 成分）：中还菜显加発生 し，骨格・筇肉・結合組織の発達がすぐれてい る。つまり，広い肩幅・愿い胸・引きしまった下 脸部というように解ばっていて重是感のある体㤠 である。

(3) 外胚葉型（第 3 成分）：外肧菜層加器生 し, 神経系・外感覚器・皮膚の発達が良好であ る。からだ全体が細長くて，弱々しい。具体的に は，扁平な胸部・平らで薄い腹部・長くて細い頸 や脚がこの体型の特幑である。

以上が Sheldon の somatotyping における $3 つ$ の基本成分の実相である。個人の形熊学的構造を 決定するために，3つの基本成分の数量化には連 続的尺度法が導入されている。それぞれの成分は 7 点法によって評定され，最高 7 ,最低 1 の rating score $か$ 内内还葉型, 中肧葉型, 外肧葉型の順にし たがって割り当てられている。それゆえ，最大の 内还葉型に分類される somatctype は 7-1-1 と表示される。

Sheldon らは1940年に anthroposcopy法と anthropometry 法を統合した somatotyping なる 新しい体格分類法を刊行した。しかし，この手法 の評定過程があまりにも複雑である上に，写真の 評価にかなりの熟練を要するため，今日ではほと んど使用されていない。現在の体格分瓶法におい て最もよく用いられている手法は，1954年に Sheldon と Dupertuis, McDermott ${ }^{15)}$ によって 作成された体型判定法; atlas 法つまり anthroposcopy 法である。この手法は18藏から65歳に至 る46,000人の男子被検者を標本にして標餅化され 
たものである。各人の somatotype の算出にあた っては，まず最初に inverse ponderal index $(\mathrm{H} / \sqrt[3]{ } \sqrt{\mathrm{W}})$ に該当する somatotype 群を著書 「Atlas of men」の年龄別の表より読み取る。 次に, 被検者の前・横・後の写真と Atlasに出て いる前記の該当 somatotype 群の写真とを比較し て, 被検者の somatotype の rating scoreを决定 する。

Sheldon ${ }^{16)}$ は多くの研究者達による anthroposcopy 法の批判を次のような 4 点に集約している。

(1) somatotype は年龄户栄養状態, 疾病, 運 動の実施程度によって変化する。

(2) somatotype の决定は客観的ではなく，主 観的である。

(3) somatotype の基本成分は 3 つではなく, 2 つである。

(4) somatotype はボディ・サイズの因子を省 略している。

こうした批判に刺激されて, Sheldon'16) は1969 年に従来の somatotyping の久点を克服する新し い手法一trunk index 法 (以下 T.I. 法と省略す

る）を公表している。この手法の完成によって, Sheldon は上記の 4 つの批判に十分対応できるも のであると主張している。さらに，従来のSheldon の方法は18歳以上の男性の体格䂓型のみに適用で きるものであるが，T.I. 法は18藏以上の女性にも 適用することが可能である。

Parnell12),13) は骨端幅と筋肉の周径，皮脂厚な どといった人体計澌值の合成得点のみから somatotype の基本成分の rating score を算出してい る。この手法は M 4 偏差四法と呼ばれ， somatotype の anthropometry 法の代表例のひとつであ る。

Heath 4),5)はM 4 偏差図法と Sheldon $の$ atlas 法を修正し，Carter とともに Heath-Carter anthropometric somatotype 法6)（以下H.-C.法 と省略する）なる新しい体格類型法を完成してい る。この体型判別法は10項目の身体計揤做から，

3 つの基本成分の rating score を算出すること ができる客観的方法である。この H.-C. 法の出 現によって， somatotyping の世界において始め て，両性・どの年秢にも適用できる方法論が確立
したと言える。

trunk index 法は本研究によって始めて日本に 紹介される方法である。一方, Heath一Carter法も 日本の大学生に適用された研究は皆無に近い状態 である。したがって，本研究の目的とする第 10 点は, T.I.法と H.一C. 法によって日本人の男女 大学生の somatotype を算出することにある。第 2 は，両手法の基本成分の rating score 間に統 計的にみて，有意な差が存在するかどうかを明ら かにする点にある。そして，最後の目的は体格類 型図表に男女被検者の体型成分をブロットして， 体格を類型化することにある。

\section{研察方 法}

1) trunk index法

(1) 被検者

男子の被㭘者富山大学数育学部の保健体育專 攻生17名之富山大学の陸上競技部員 8 名の計25名 である。女子の被検者は富山大学教育学部の保健 体育専攻生24名である。沏定は昭和54年12月の初 旬に行なわれた。被検者の基本的な統計数値は表 1の通りである。

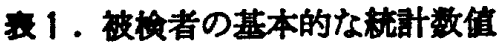

\begin{tabular}{|c|c|c|c|c|}
\hline \multirow{3}{*}{ 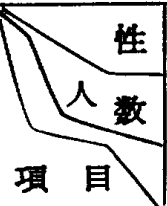 } & \multicolumn{2}{|c|}{ 男 } & \multicolumn{2}{|c|}{ 女 } \\
\hline & \multicolumn{2}{|c|}{25} & \multicolumn{2}{|c|}{24} \\
\hline & $\bar{X}$ & $\mathbf{s}$ & $\overline{\mathrm{X}}$ & $\mathbf{s}$ \\
\hline 年踰(歳) & 21.2 & 1.43 & 21.0 & 0.94 \\
\hline 身曼 $(\mathrm{cm})$ & 172.2 & 4.74 & 158.5 & 4.33 \\
\hline 体重(kg) & 64.6 & 5.97 & 55.6 & 5.29 \\
\hline
\end{tabular}

\section{(2) 撮影場面の設定}

体型撮影に用いたカメラはマミヤ・コニバーサ ル・ブラックである。白い撮影用スクリーンの前 に高さ $10 \mathrm{~cm}$ のターンテーブルを置き，レンズか らテーブルの中心までを $300 \mathrm{~cm}$ とし， レンズの高 さを床から $120 \mathrm{~cm}$ 位置にセットした。ライトは 被検者の左右それぞれ45度の角度に，テーブルの 中心から距離，高さともに150cm の位置に備え付 けた。ライトは $500 \mathrm{~W}$ のものを左在 1 個ずつ使用 している。正面の $300 \mathrm{~W}$ のライは被检者から $250 \mathrm{~cm}$ の距離を取り， $75 \mathrm{~cm}$ の高さから顔に向け 
てセットした。

被検者はターンテーブル上で両踵を5 $\mathrm{cm}$ 離し, 爪先を45度に開いて直立する。指先はしっかりと
伸ばして体側から $15 \mathrm{~cm}$ 離す。男性は海水着パン

ツ，女性はレオタードを着用して撮影した。

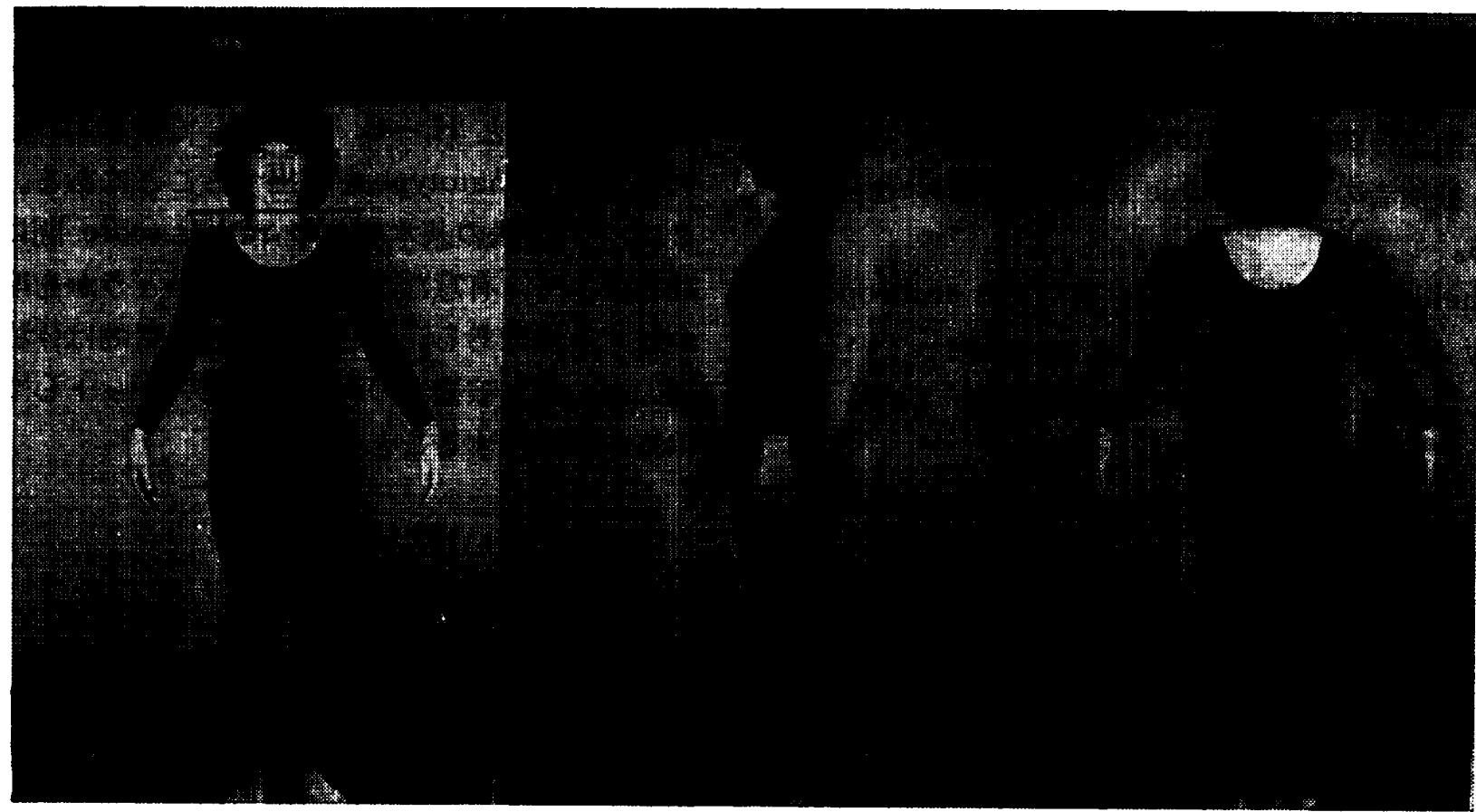

图 1. trunk index 法による女性の somatotype

$$
3 \frac{1}{2}-3 \frac{1}{2}-3 \frac{1}{2}
$$

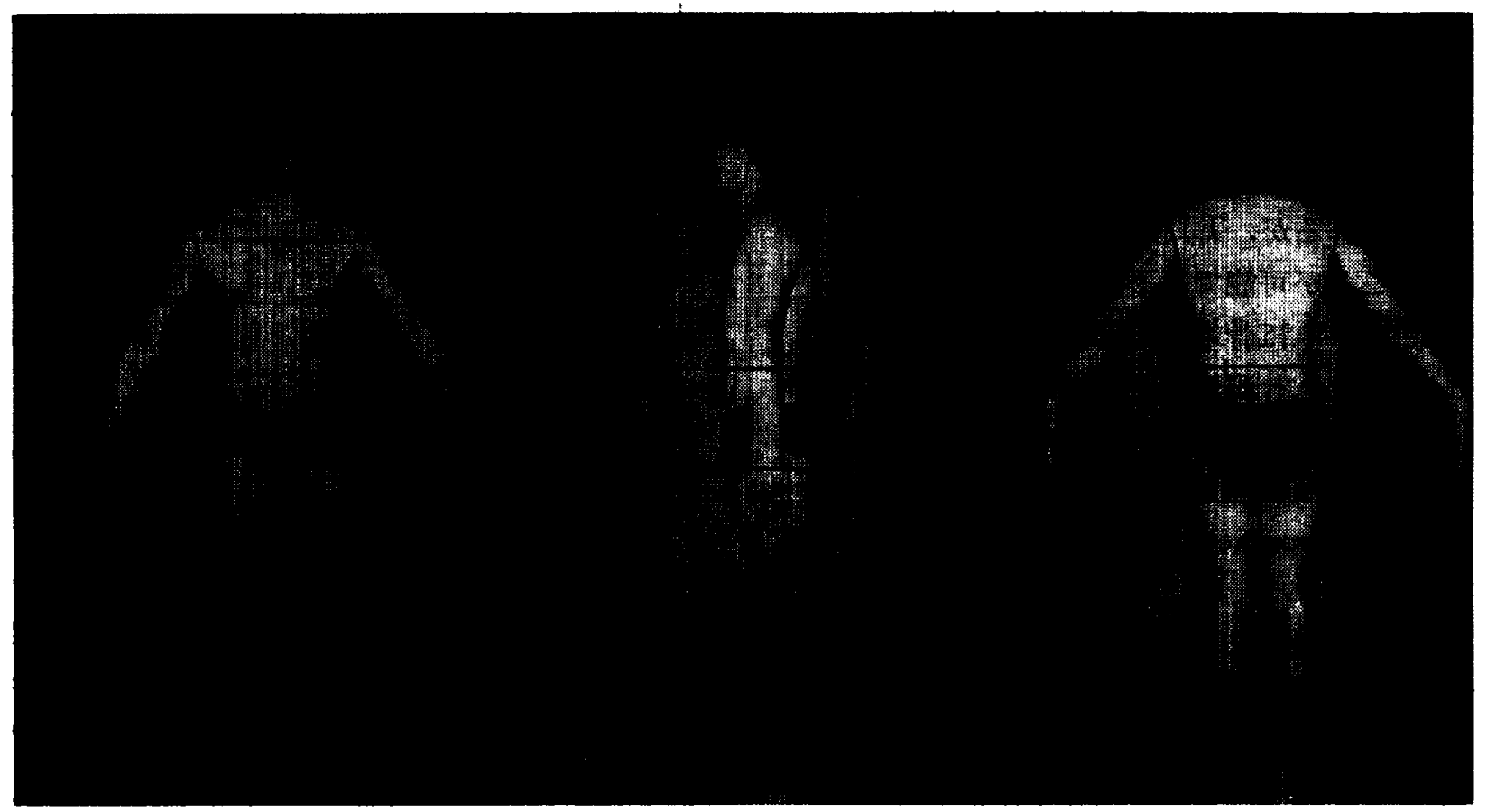

因2. trunk index 法による男性のsomatotype

$$
2-6 \frac{1}{2}-1 \frac{1}{2}
$$


(3) somatotype の算出法16)

trunk index は被検者の写真の胸部之腹部の面 積をプランメーターによって測定して算出され る。体型の写真撮影では、 コダックの $6 \mathrm{~cm} \times 9 \mathrm{~cm}$ の白黑用フィルムを用いて，被検者の前面・左側 面・背面の 3 葉の写真が撮影された。次に,これら 3 枚の写真をキャビネ版に引き伸ばして trunk indexの算出に用いた。

胸部の区域を決定するためには，まず，首の両 側に僧帽筋が胸鎖乳突筋と交わってできる行度の 中心を印し，その 2 点を結んで頭部を切り離す。 次に，左右の肩の三角筋で形成される外側の弧の 中心之，腋の下のくぼみの最上点を結んで両腕を 切り韵す。胸部と腹部の境界線は前面写真と侧面 写真の 2 枚を用いて見つける。腸骨稜の頂点と助 骨下部の一番くぼんでいる点との距離の 2 等分点 を左右に結んだ線が，まず仮の区分線となる。側 面写真では，腰角度の中心（腰の最もくぼんだ 所）を通って床に水平な直線を引けばよい。仮の
区分線とこの腰の直線が一致すればこれが胸部 と䧗部の区分線である。もし一致しない場合に は，2線の中閏に位置する線を最終の区分線とす る。上記の 4 本の線と体側と肩の線で四亡れた部 分が胸部の面䅡となる。

腹部の上限線は胸部との区分線であり，下限線 は譬と腿でできた角度（㛭部の下のくぼみ）の中 心を通る水平線である（因1，因2）。

论にプラニメーターを用いて前面の胸部, 腹 部; 背面の胸部，腹部をそれぞれ 3 回ずつ計 溯 し，その 3 回の平均値を取って胸部と腹部の面頪 とした。胸部の值を腹部の值で割り，100 倍した ものが trunk index である。

T.I. 法では, T.I. と年齢，身長（インチ）と 身長を体重（ポンド）の平方根の 3 乗で割った值 (somatotyping ponderal index(SPI) $: \mathrm{H} /{ }^{3} \sqrt{\mathrm{W}}$ ) がわかればあとは Sheldonの換算表から被榆 者の somatotype を求めることができる(表 2 )。 なお，T.I.法では，身長と SPI の值は soma-

㿪 2. Sheldon の trunk index 法による somatotype 换算表

The basic tables for somatotyping

(シェルドンより引用)

SPI with maximal weights at progressive ages

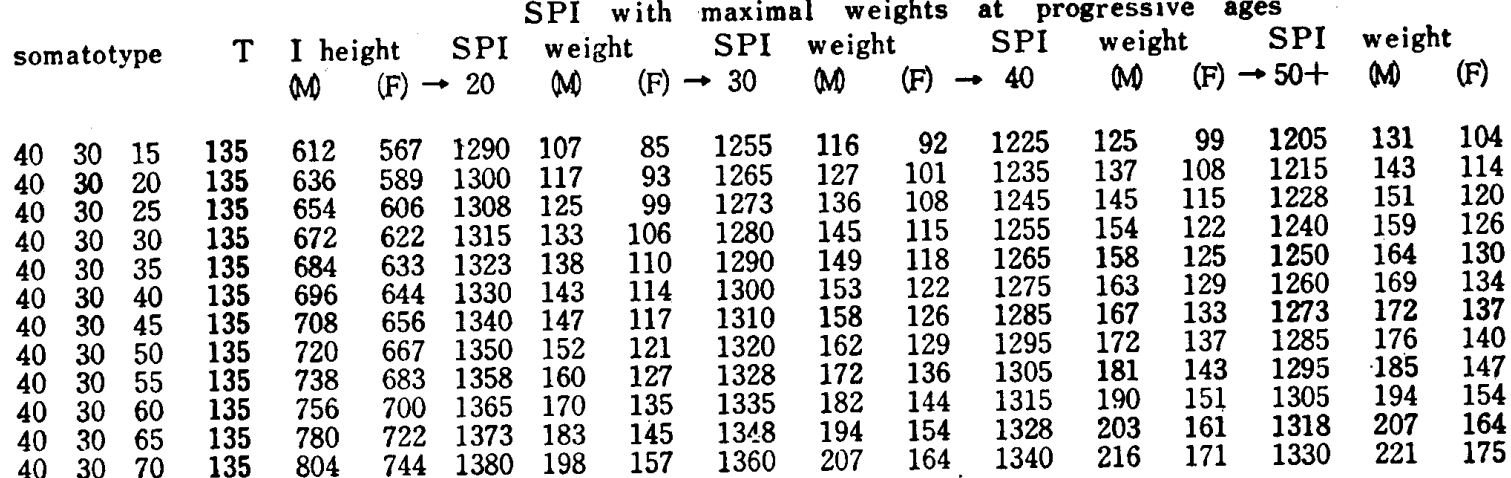

totype 算出する時点までの, 前者は最大值, 後者 は最小値を用いるものと規定されている。

2) Heath-Carter 法

(1) 被检者

男女とも T.I. 法と同一被検者であり，男子 25 名, 女子24名である。测定は昭和54年11月中旬か ら12月初旬にかけて実施された。

(2) 測定項目と测定器具

H.一C. 法による体型の評定に対しては，次の 計測值が必要である。身長，体重，4部位の皮下 脂肪厚（右上腕三頭筋部・右側の肩甲骨下部 - 右
侧の腸学稜上部・右脚下腿背部), 右上腕骨之右 大腿骨の骨端偪，右腕の最大届曲上腕困，右脚の 最大下煺国の計10項目である。

皮脂厚は明興社の柴研式皮下脂肪計によって， 骨端幅と上腕囲，下眼囲は竹井機器工業のマルチ ン式人体測定器によって計揤した。

(3) somatotype の算出法6),3),8),7)

HebbelinckとRoss7) によって作成されている 表 3 : Heath-Carter somatotype rating form にデータを代入することによって，各自の体型か 决定される。 
輚 3. Heath-Carterのsomatotype rating form (Hebbelinck et al.より引用)

Heath-Carter somatotype rating form

\begin{tabular}{cc} 
First Component(Endomorphy) \\
\hline Sum of Skinfnolds, mm & Rating \\
\hline $7.0-10.9$ & \\
$11.0-14.9$ & 1 \\
$15.0-18.9$ & 2 \\
$19.0-22.9$ & $2 t$ \\
$23.0-26.9$ & 3 \\
$27.0-31.2$ & $3 \frac{1}{t}$ \\
$31.3-35.8$ & 4 \\
$35.9-40.7$ & 5 \\
$40.8-46.2$ & $5 \frac{1}{t}$ \\
$46.3-52.2$ & 6 \\
$52.3-58.7$ & $6 \frac{1}{2}$ \\
$58.8-65.7$ & 7 \\
$65.8-73.2$ & $7 \frac{1}{t}$ \\
$73.3-81.2$ & 8 \\
$81.3-89.7$ & $8 \frac{1}{2}$ \\
$89.8-98.9$ & 9 \\
$99.0-108.9$ & $9 \frac{1}{2}$ \\
$109.0-119.7$ & 10 \\
$119.8-131.2$ & $10 \frac{1}{2}$ \\
$131.3-143.7$ & 11 \\
$143.8-157.2$ & $11 \frac{1}{2}$ \\
$157.3-171.9$ & 12 \\
$172.0-187.9$ & \\
$188.0-204.0$ & \\
&
\end{tabular}

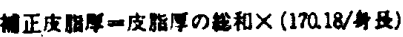

Second Component (Mesomorphy)

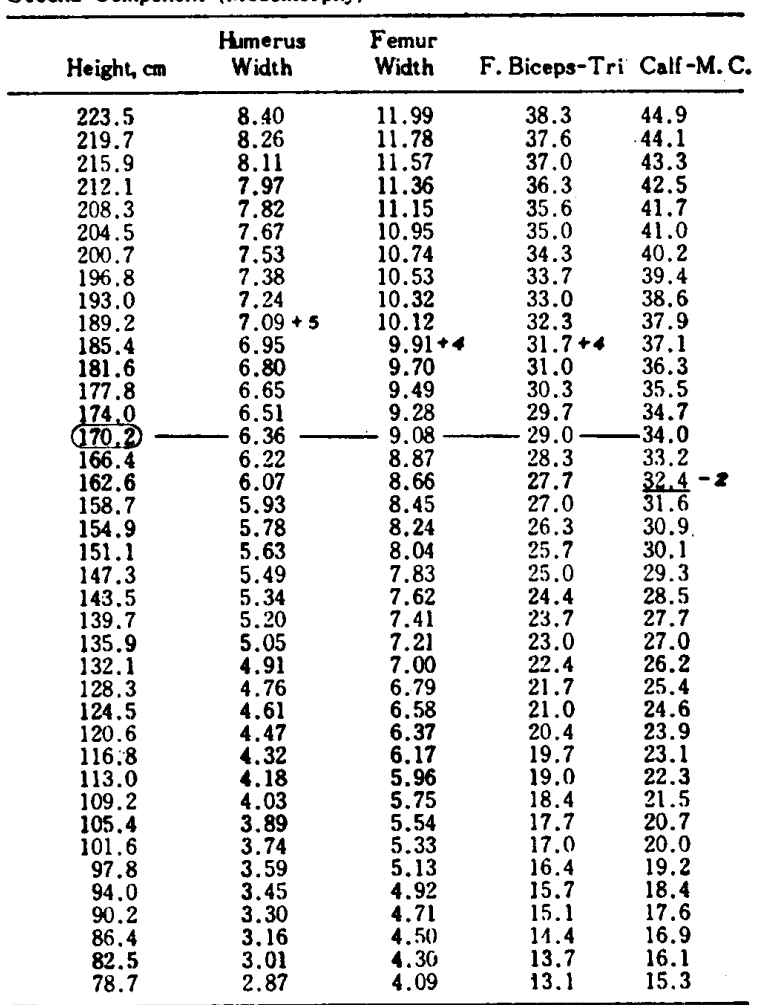

Third Component (Ectomorphy)

\begin{tabular}{cc}
\hline$H / \sqrt[3]{W}$ & Rating \\
\hline up to 11.99 & $t$ \\
$12.00-12.32$ & 1 \\
$12.33-12.53$ & $1 t$ \\
$12.54-12.74$ & 2 \\
$12.75-12.95$ & $2 t$ \\
$12.96-13.15$ & 3 \\
$13.16-13.36$ & $3 t$ \\
$13.37-(13.56)$ & $6)$ \\
$13.57-13.77$ & $4 t$ \\
$13.78-13.98$ & 5 \\
$13.99-14.19$ & $5 t$ \\
$14.20-14.39$ & 6 \\
$14.40-14.59$ & $6 t$ \\
$14.60-14.80$ & 7 \\
$14.81-15.01$ & $7 t$ \\
$15.02-15.22$ & 8 \\
$15.23-15.42$ & $8 \frac{1}{2}$ \\
$15.43-15.63$ & 9 \\
\hline
\end{tabular}

第 1 成分（内胚葉型）は上腕三頭鉴部之肩甲骨 下部, 腸骨稜上部の皮脂厚の総和に対応する rating score を表から読み取ることによって求め られる。

第 2 成分 (中肧葉型) は表 3 を用いて算出す る。第 2 成分の評定に必要視される 5 つの变量は 身長，上腕骨と大腿骨の骨端幅，皮脂厚を減じた 上腕部と下俍部の最大周径である。第 2 成分の rating score は次の式で与えられる：

$$
\text { rating score }=4+\frac{1}{8} \times \mathrm{D}
$$

（ただし，Dの值は被検者の身長基準ラインから カウントされる 4 変量の総和である)

なお，H.一C. 法では計算された somatotype のrating score は0.5 単位で表示することになっ ている。

第 3 成分 (外㱬葉型) はT.I. 法で用いたinverse ponderal index $(\mathrm{H} / \sqrt[3]{\sqrt{W})}$ の值を表 3 の数值と 対比して决定する。

3つの基本成分を体格類型図表上に表わすには 次の公式を用いる7：

$$
\begin{aligned}
& \mathrm{X}=\mathbb{I I}-\mathrm{I} \\
& \mathrm{Y}=2 \mathrm{II}-(\mathrm{I}+\mathbb{I I}) \\
& (\mathrm{I}, \mathrm{II}, \mathbb{I I} \text { は基本成分の rating score) }
\end{aligned}
$$
体格類型図表上では，体型は大きく5つのタイ プに分類される3)。第 1 成分の rating scoreのみ が 5 以上の場合 : 内阫葉タイブ，第 2 成分のみが 5 以上の場合 : 中肧葉タイプ，第 3 成分のみが 5 以上の場合：外还葉タイプ，第 1 第 2 成分がとも に 5 以上である場合：内・中肧葉タイプと命名し ている。 3 成分とも 5 末満と rating score され れた場合：中間タイプと名付けている。

\section{結果と考察}

Sheldon の trunk index 法も Heath-Carter 法も成人男女に適用可能な体型判定法である。 T.I. 法に扔いて要求される被榆者の minimum somatotyping ponderal index と成人時の最大 身長值は，本研究では，測定時点の身長と体重を 用いることによって，決定できるものと仮定して 算出している。 
衰 4. Heath-Carter 法に必要な測定項目の平均值・標準傓差と信頼性保数

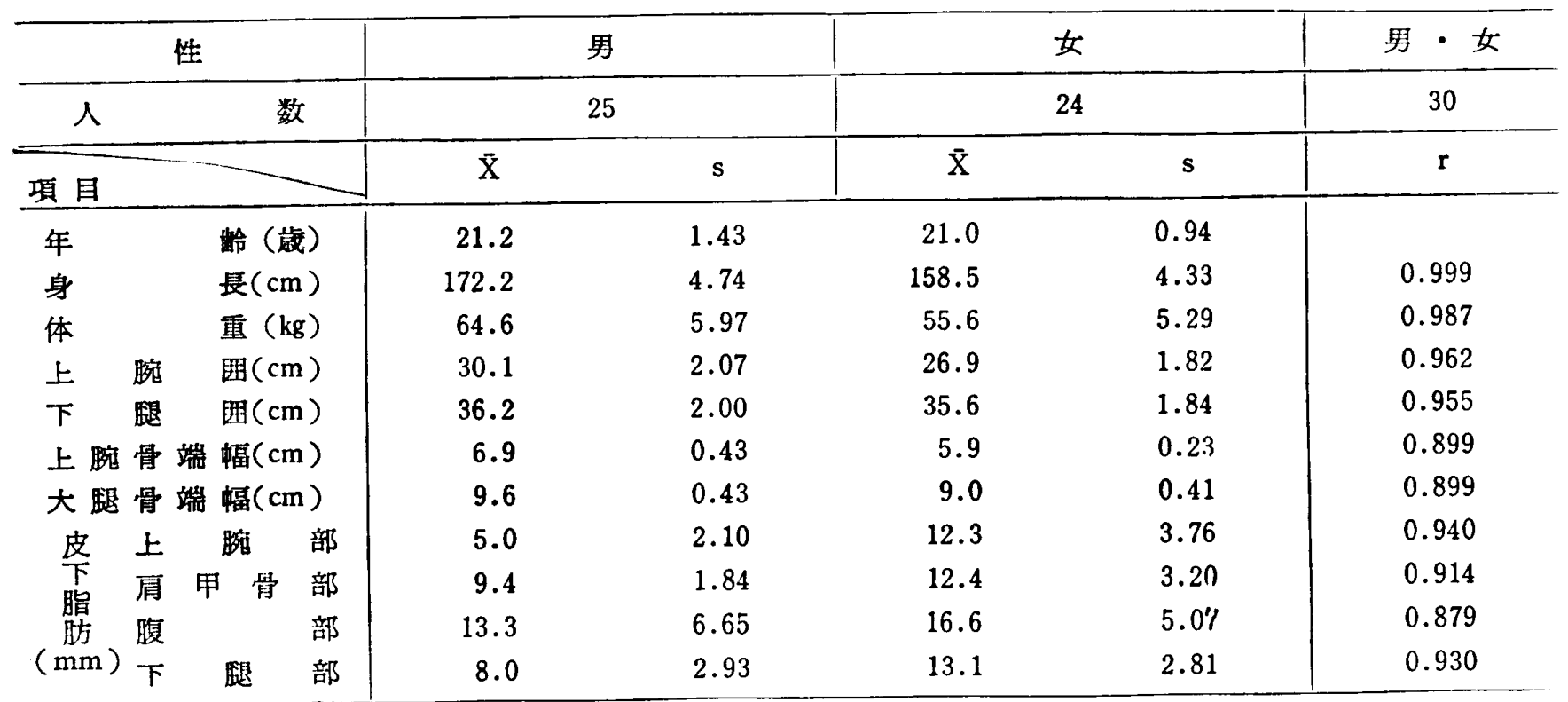

表 4 は H.-C. 法に必要な测定項目の平均值と 標準保差である。揤定項目の精度をチュックする ために，男女の被榆者の中から各々15名ずつ抽出 し，10項目からなる湘定值の信頼性俰数を求めて いる（表 4)。前後二度にわたる形態測定には，約 1ケ月閒の期間を置いて実施した。测定項目の信 頼性係数は腸骨稜上部つまり腹部の皮脂 厚 0.879 と両骨端幅の 0.899 以外は 0.9 以上の高い值であ り，再現性の高さを物語っている。つまり，これ らの結果は, H.-C. 法の計揤值の信頼性係数とし ては満足のゆくものである。

男子に打いて両手法の成分を比較してみると， 各成分とも類似した值を示している。統計的にみ ても有意な差は各成分の平均值間に認められない 結果となっている（表5)。したがって，本標本

表 5. trunk index 法と Heath-Carter 法による somatotype の平均值と標準偏差（男）

\begin{tabular}{|c|c|c|c|c|}
\hline \multicolumn{2}{|c|}{$F_{\text {泩 }}$ 成 分 } & 内肧葉型 & 中还葉型 & 外肧菒型 \\
\hline \multirow{2}{*}{ T. I. } & $\overline{\mathrm{X}}$ & 2.8 & 4.9 & 2.9 \\
\hline & $\mathbf{s}$ & 1.05 & 0.99 & 1.02 \\
\hline \multirow{2}{*}{ H. - C. } & $\overline{\mathrm{x}}$ & 2.4 & 5.0 & 3.1 \\
\hline & $\mathbf{s}$ & 0.88 & 1.04 & 1.13 \\
\hline の & 值 & 1.433 & -0.345 & -0.645 \\
\hline
\end{tabular}

と類似した体格を類型化する場合，両手法とも同
じような結果に各成分を判別すると言える。

Morton 10) は H.-C. 法と密接に関連している Heath の anthroposcopy 法と T. I. 法との関倸 を解析している。男子16歳（106名）にみられる3 成分の平均䛧を比較すると，第 1 成分のみ $1 \%$ 水 準で T. I. 法が有意に高い。残りの 2 成分に関し ては両手法の間に，統計的にみて有意な差はない と報告している。

Carter 1) はニュージーランドの男子体育専攻 生60名に H.-C. 法を実施して, somatotype の rating score を算出している。その結果，平均身 長176.3 cm, 平均体重72.6kgである被梌者の内还 葉型の平均値は2.5, 中还葉型は5. 4 , 外还葉型は 2.1であった。類型化された somatotype は日本の 体育専攻生のそれに似通っている。外眼葬型で両 群の間に1.0の段階差がみられる程度である。両群 とも顕著な中还葉タイプに集中する傾向にある。

Wilmore ${ }^{18)}$ はアメリカの一般男子大学生133名 の体型判定に H.-C. 法を適用している。彼らは 4. 0-5.1-2.3なる rating score を獲得して, 内 阫藮型で体育専攻生より有意に高い体型となって いる。つまり，皮下脂肪の厚い体格が一般学生の 特徴である。

女子の場合は，第 1 成分において $1 \%$ 水準で， H.-C. 法が高い得点を獲得している。表 6 より， 両手法間には 1.0 段階程度の差が存在している。 
H.-C. 法の被検者の第 1 成分は皮脂厚 の 総和に （170.18/各人の身長）なる涟を乗じて算出され る関係上, T.I. 法よりも内肧葉型の要素が強く出 る原因のひとつであると撨揤できる。第 2 ・第 3 成分の間に流，統計的にみて有意な差は存在して いない。

Slaughter 17 らはアメリカの一般女子大笔生 31 名の somatotype を T.I. 法と H.-C. 法の両手 勆によって隶的ている。アメリカの一般学生で

表 6. trunk index 法上 Heath-Carter 法による

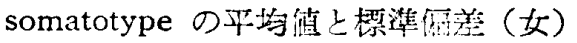

\begin{tabular}{|c|c|c|c|c|}
\hline \multicolumn{2}{|c|}{ 手法 } & 们肧葉型 & 中亚程型 & 外踎㕖型 \\
\hline \multirow{2}{*}{ T. I . } & $\bar{x}$ & 3.6 & 4.7 & 2.5 \\
\hline & $\mathrm{s}$ & 0.86 & 0.81 & 0.83 \\
\hline \multirow{2}{*}{ H. $-\mathrm{C}}$. & $\overline{\mathrm{x}}$ & 4.5 & 4.5 & 2.0 \\
\hline & s & 1.14 & 0.84 & 0.88 \\
\hline の & 值 & $-3.087^{* *}$ & 0.840 & 2.025 \\
\hline
\end{tabular}

**印は 1 \%の有意水準を示す。

は，第 1 成分は有意でないが，T.I. 法の第 2 ・第 3 成分の rating score が $5 \%$ 水準でH.-C.法のそ れらより高くなっている。日本の体育样攻生と比 較すると，第 1 成分ではアメリカの学生の方が両 手法に打いて有意に高い。両手法ともに 5 以上の rating score になっているので皮下脂肪の蓄稳し たかなり肥䓜の目立った体型であると言党る。

Carter 1) はニュージーランドの平均身是164.3 $\mathrm{cm}$, 平均体重 $60.0 \mathrm{~kg}$ ある女子体等禁攻生の somatotype を H.-C. 法によって算出している。 被榆考総数61名の rating score は3.9-4.4-2.2 であった。中还葉型と外还菜型の rating score は日本の体育専吹生のそ机らに酷似している。内 肧葉型は 3.9 と 4.5 というように有意に異ってい るが，約 $6 \mathrm{~cm}$ の身長差放こうした結果のひとつ の原因として刻げることがで方。

Wilmore ${ }^{18)}$ はアメリカの一般女子大学生128名 の价型を H.C. 法によって求めている。各成你の 得点は 4.1-3.8一-2.5であり，日本の体育専攻生 より中还葉型で劣り，外肧葉型で高い得点定獲得 している。
図 3-田 5 は両手法の各成分間の相関関保を表 わしたものである。第 1 ，第 2 成分は男女とも

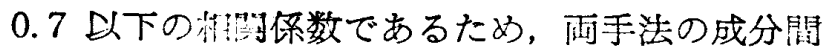
に高い相関関倸があるとは言えない結果となって いる。第 3 成分においては，男女とも 0.8 以上と いった高い関連の度合が見られ，この成分に関し

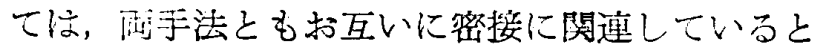
㝘える。

Morton 10）の16歳男子に打ける両手法の相関倸

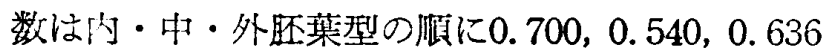
となっている。Slaughter17) の平均年路19.8歲文 子にみられる両手法の相関俰数は順に0.79,0.54, 0.88 である。本研究の中肧葉型における男文の相
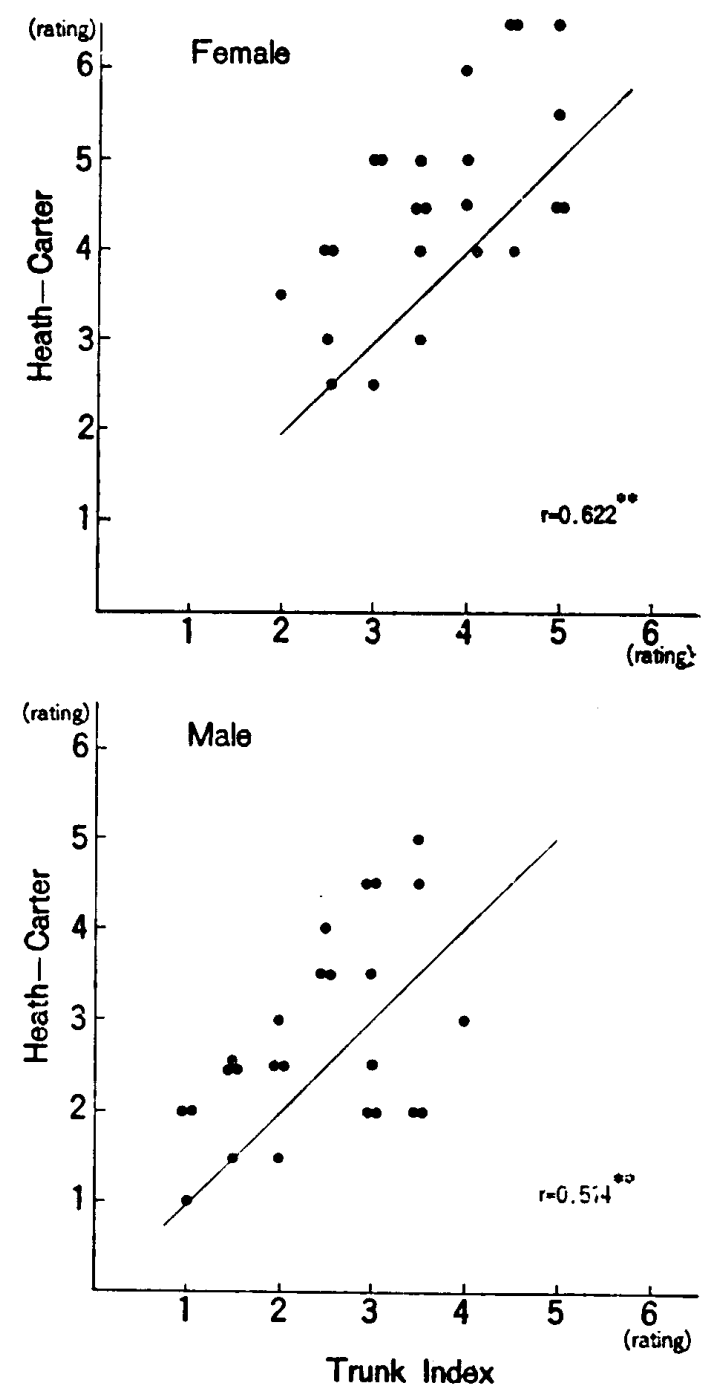

図3. trunk index 法と Heath-Carter 法乞の相 时図 (内还葉型) 

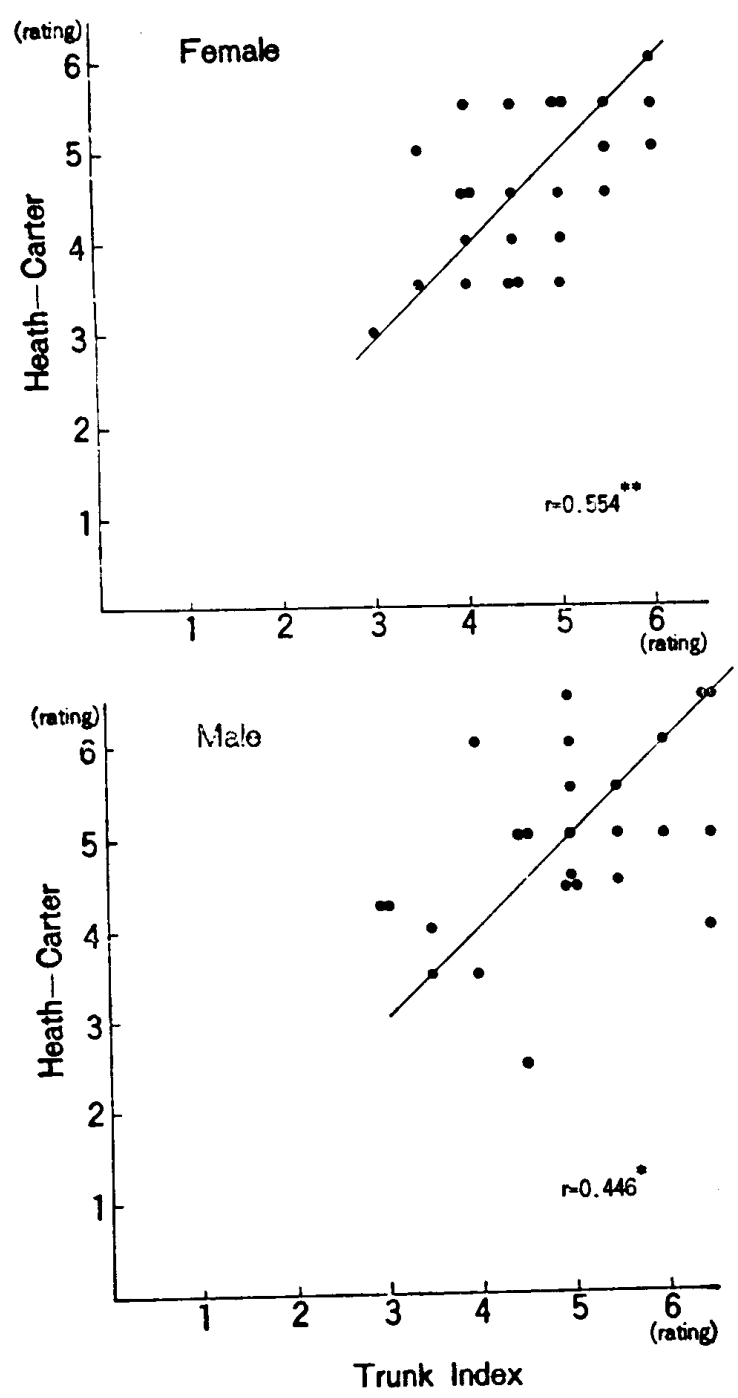

图 4. trunk inciex 法とHeath-Carter 法上の相 获图（中目热型）

関倸数はそれぞれ0.446，0.554であり，Morton や Slaughter の結果に符合するものである。こ うした中还萖型のかなりといった相関係数の関連 程度は两手法の算出方法に起因していると推察で きる。つまり，H.-C. 法では身長あたりの相対的 な筋肉と骨格の恣育から，T.I. 法では胸部と腹 部との面積の比から算出している点にある。内肧 葉型における相関保数诘 Morton, Slaughter の 闹方の值も 0.7 以上であり，高い関運性を示して いる。しかし本研究の男子では 0.5 台の涟である。 その一因を T.I. 法は主として身長と体重に, H.-C. 法は主として体重こ体脂肪に密接に関連し ているといった点闪求めることができる。

次に，相関図表に45度の勾配の直線な引いて両 手法間の関倸をながめてみる。もし，45度の直線
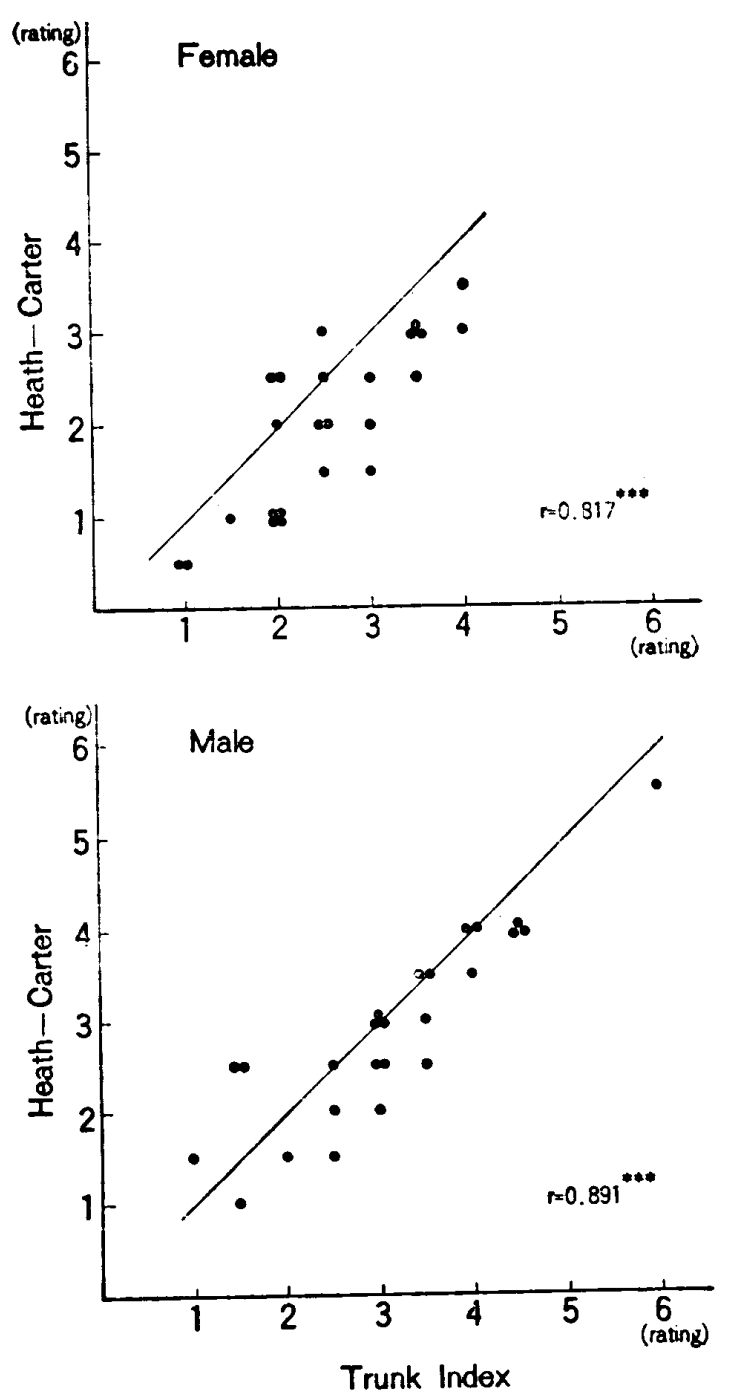

图 5. trunk index 法と Heath-Carter 法との相留 図(外柤葉型)

上にすべてのデータが散布した場合，相関係数は 1.0であり，被検者の成分は両手法で全く同じ段 階に判別されたと解釈できる。第 3 成分において は, 男女とも45度の線よりも下に位置する被検者 の数が圧倒的に多く, T.I. 法に高い rating score 台与えられる判定法となっている（図 5)。

前記の第 3 成分の相関倸数は男性 0.891 , 女性 0.817という漓い值であったので，両手法とも密 接に関連していると解积された。相関保数という 統計量の特徴として，相関保数の高低にデータ散 布の勾配は関倸しない。つまり45度より急な勾配 あるいはなだらかな勾配を持った線型関係です， 高い相関保数を持つ可能性が十分考号られる。例 总壮，女性の第 3 成分 (外还葉型) の線型関俰に おける公配，つまり回帰係数 $(b=0.87)$ は45度 
皿 7. trunk index 法と Heath一Carter 法による somatotype の最小值と最大傎

\begin{tabular}{|c|c|c|c|c|}
\hline & 成 分 & 内胚葉型 & 中肧葉型 & 外肧葉型 \\
\hline 男 & $\begin{array}{l}\text { T. I. } \\
\text { H. }-\mathrm{C} .\end{array}$ & $\begin{array}{l}1.0-4.0 \\
1.0-5.0\end{array}$ & $\begin{array}{l}3.0-6.5 \\
2.5-6.5\end{array}$ & $\begin{array}{l}1.0-6.0 \\
1.0-5.5\end{array}$ \\
\hline 女 & $\begin{array}{c}\text { T. I. } \\
\text { H. }- \text { C. }\end{array}$ & $\begin{array}{l}2.0-5.0 \\
2.5-6.5\end{array}$ & $\begin{array}{l}3.0-6.0 \\
3.0-6.0\end{array}$ & $\begin{array}{l}1.0-4.0 \\
0.5-3.5\end{array}$ \\
\hline
\end{tabular}

よりもなだらかな勾配を持っている。したがっ て，X軸の T.I. 法の rating score はY軸のH.-C. 法のそれよりも，高い確率でもって甘く評定され る可能性が大であると言える。

逆に，第 1 成分では45度の線よりも上に H.-C. 法の被検者が集中している。両手法を使って，第 1 成分の rating score を算出する場合には, H.-C. 法の方が甘い得点方式とみなすことがで きる。第 2 成分に関しては，男女とも平均值には 有意差がないが，あまり高くない相関保数となっ ている。男女とも45度の線を境にしてほぼ対称に 分布しているが，線型関係が他の成分に比較して 希涾になる傾向にある。

表 7 は男女別の各成分の最小值と最大值を示し たものである。男子の各成分のレンジは $3-5$ の 䦭に位置し，女子のレンジは 6 個のうち 5 個まで が 3 となっている。したがって，女子学生に関する 限り，各成分のレンジは手法に関係なくほぼ等し い值と言える。男子の場合，第 1 ，第 2 成分では H.-C. 法が大きなレンジを有し，第 3 成分では T.I. 法のレンジの值が大きくなっている。

内肧葉型で 6,7 といった顕著な肥満傾 向を 示す被検者は男子ではゼ口であり，女子において も H.-C. 法にみられる24名中 4 名にすぎない実 態である。さらに，T.I.法を採用すれば女子もゼ 口となる。つまり，本研究の被検者は体育専攻生 乞陸上競技部具であり，大多数運動部に所属して いるといった点が上記の結果を反映しているもの と推测できる。

中胚葉型では，運動部に所属しているといった 被検者の特性が影響して，49人中 48 人までが 3 以 上の rating score を獲得している。最後に, 外 肧葉型では，ひとりの例外を除き全員が 5 以下の
衣 8 ・性別にみた体型の度数分布

\begin{tabular}{|c|c|c|c|c|}
\hline 性 & \multicolumn{2}{|c|}{ 男 } & \multicolumn{2}{|c|}{ 女 } \\
\hline タイプ 法 & T. I . & $\mathrm{H},-\mathrm{C}$. & T. I . & $\mathrm{H} .-\mathrm{C}$. \\
\hline 内眼葉タイブ & 0 & 0 & 3 & 4 \\
\hline 中肧葉タイプ & 16 & 14 & 10 & 5 \\
\hline 外胚葉クイプ & 1 & 1 & 0 & 0 \\
\hline 内·中胚葉タイブ & 0 & 1 & 1 & 5 \\
\hline 中間タィプ & 8 & 9 & 10 & 10 \\
\hline
\end{tabular}

rating score であり，貝弱で細長い体型とは䀣 け離れた存在である。

体格類型表によれば，男子は中肧葉タイプに T.I. 法で16名, H.-C. 法で14名分類されている (表 8 )。男子の約 6 割は中肧葉タイプであり， 残りは大部分中間タイプに位置付いている。女子 は手法によって，体型分布が異っており，T.I. 法 では中肧葉タイプ10名, H.-C. 法ではその半分の 5 名である。H.-C. 法の残りの 5 名は内胚葉型の 影響を受けて，内・中肧葉タイプにながれている

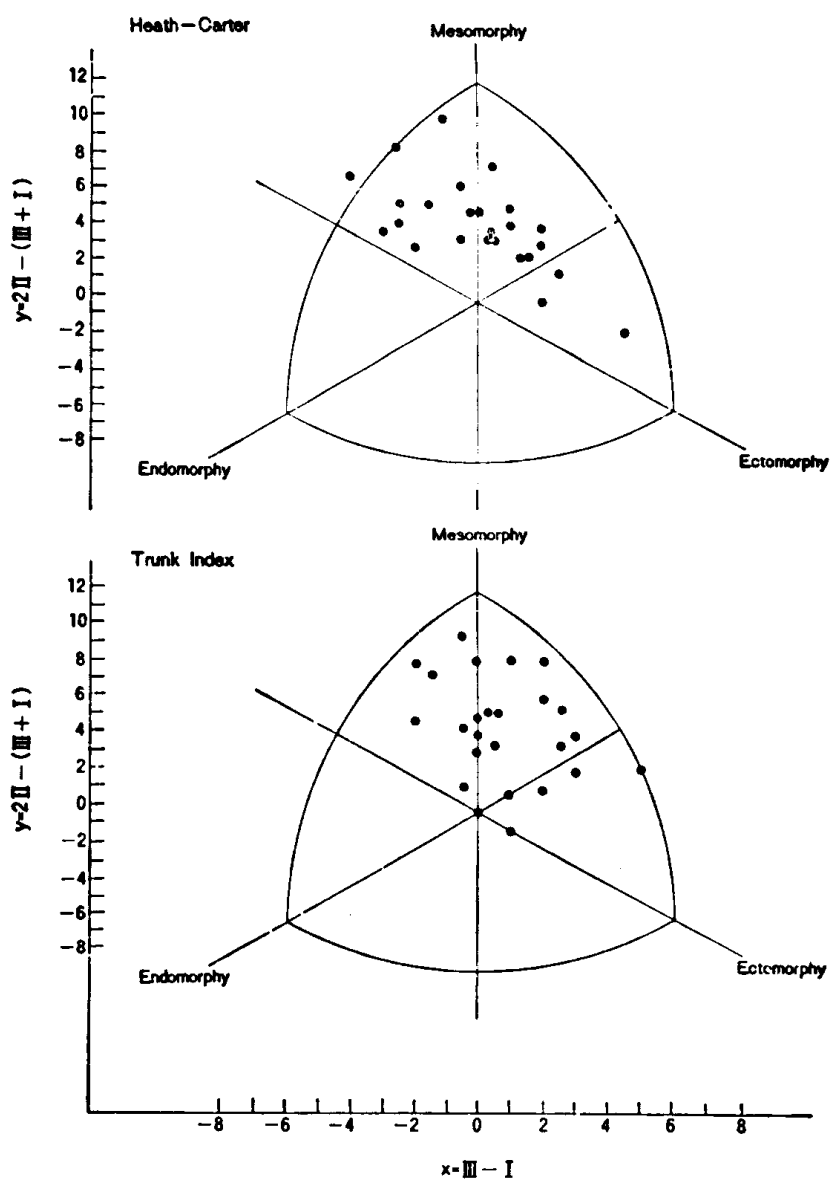

图6.男子体育尃攻生と陸上競技部員との体格類型 図装（Hebbehnck Rcssの図を使用） 


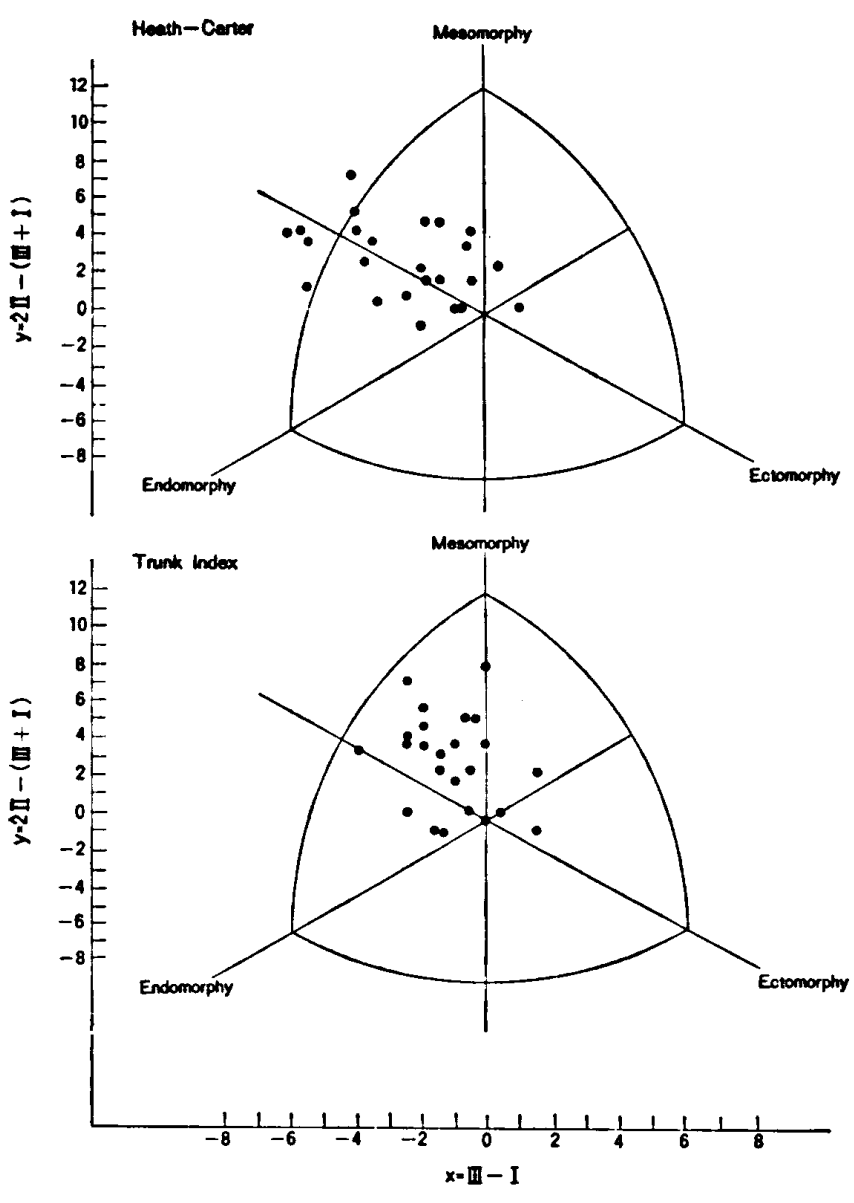

因 7.女子体充専呚生の体格類型図表 (Hebbelink と Ross の四を使用）

公算が大きい。男子ではゼ口の内肧葉タイプに T.I. 法で 3 名, H.-C. 法で 4 名が属している。残 りの䄪 4 割は中間タイプである。

図6 と図7は体格類型図表に，T.I. 法と H.-C. 法別に被検者の各成分の rating score をプロッ トしたものである。

\section{結語}

男子体育専攻生 17 名, 陸上競技部員 8 名の計 25 名と女子の体育専攻生 24 名の somatotype を Sheldon $の$ trunk index 法と Heath-Carter の anthropometry 法によって解析した結果，下記 のような知見を得たので報告する。なお，結果は 本研究に用いた標本や somatotype の算出手法の 限界内で一般化することが可能である。

1）男子被検者の trunk index 法と anthropometry 法によって評定された $3 つ の$ somatotype の基本成分（内肧葉型，中还葉型，外还葉型）の 平均值は2.8一- $.9-2.9$ と2.4-5.0-3.1である。
2）両手法による女子被㭘者の基本成分の平均 値は3.6-4.7一2.5と4.5-4.5一-2.0である。

3）男性において, 両手法の内肧葉型, 中肧葉 型，外还葉型の平均值間には $\mathrm{t}$ 検定の結果，すべ ての型に有意な差が存在しない。

4）女性においては，両手法の内肧葉型の平均 值間に $1 \%$ 水準で有意な差が存在している。つま り, anthropometry 法の rating score の平均值 は有意に高く，高い確率でもって調查対象群を肥 満集団と評定する傾向にある。中肧葉型と外胚葉 型においては，有意な差は認められない。

5）男女とも，両手法の各成分の相関係数はす ベて $5 \%$ または 1\%水準の有意性を示している。

6）両手法間に打ける内还葉型，中肧葉型，外 肧葉型の相関你数は男性では $0.514,0.446,0.891$ であり，女性では $0.622 ， 0.554 ， 0.817$ である。

7） trunk index 法と anthropometry 法によ つて5つのタイプに大別される内还葉タイプ，中 肧葉タイプ, 外肧葉タイプ, 内・中肧葉タイプ, 中間タイプに対する男性の度数分布は $0-16-1$ -0-8 と0-14-1-1-9 となり, 女性の度 数分布は $3-10-0-1-10$ と $4-5-0-5-$ 10 と分散する。

本研究の実施に当たっては, 島田幸子先生に多大の 御協力をいただきました。深甚の謝意を表します。

\section{引用・参考文献}

1) Carter, J.E.L., "The somatotype of athletesa review," Hum. Biol., 42:535-69,1970.

2) Carter, J.E.L. and Heath,B.H., Somatotype methodology and Kinesiology research. in Kinesiology Review, American Association for Health, Physical Education, and Recreation, Washington, D.C,1971. pp. 10-19.

3) Clarke, H.H., Physical and motor tests in the Medford boys' growth study, Prentice-Hall : Englewood Cliffs, N.J., 1970. pp.48-96.

4) Heath, B.H., "Need for modification of somato typing methodology," Am. J. Phys. Anthrop., 21 : 227-33, 1963.

5 ) Heath, B.H.and Carter, J.E.L., "A comparison of somatotype methodology," Am. J. Phys. Anthrop., $24: 87-99,1966$. 
6) Heath, B.H. and Carter, J.E.L., "A modified somatotype method," Am. J. Phys. Anthrop., 27 : 57-74, 1967.

7) Hebbelinck, M. and Ross, W.D., "Body type and performance," in Larson, L.A. (Ed.), Fitness, health, and work capacity, Macmillan Publishing Co., Inc. : N.Y., 1974.pp. 266-83.

8 ) Karpovich, P.V. and Sinning, W.E., Physiology of muscular activity, W.B. Saunders Co. : Philadelphia,1971. pp. 295-304.

9) クレッチメル(相場均訳)，体格と性格, 文光堂, 1960 . (Kretschmer, E., Körperbau und Charakter, Springer : Berlin, 1921.)

10) Morton, A.R., Comparison of Sheldon's trunkindex and anthroposcopic methods of somatotyping in their relationships to the maturity, structure, and motor ability of the same boys nine through sixteen years of age. Microcard Doctoral Dissertation, University of Oregon, 1967.

11）南山堂, 医学大辞與, 第16版, 南山堂, 1978. p. 1275 .
12) Parnell, R.W., " Somatotyping by physical anthropology," Am. J. Phys. Anthrop., 12 : 209-39, 1954.

13) Parnell, R.W, Behaviour and physique, Edward Arnold Ltd. : London, 1958. pp.13-35.

14) Sheldon, W.H., Stevens, S.S. and Tucker, W.B., The varieties of human physique, Harper and Bros. : N.Y., 1940.pp.29-107.

15) Sheldon, W.H., Dupertuis, C.W. and McDermo$\mathrm{tt}$, E.,Atlas of men, Harper and Bros. : N.Y., 1954. pp. 11-34.

16) Sheldon, W.H., Lewis, N.D.C. and Tenney, A. M., "Psychotic patterns and physical constitution," in Schizophrenia, D.V.S. Sankar, (Ed.), PLJ Publications Ltd. : Hicksville, N.Y., 1969. pp. 838-912. 17) Slaughter, M.H. and Lohman, T.G., "Relationship of body composition to somatotype," Am. J. Phys. Anthrop., $44: 237-44,1970$.

18) Wilmore, J.H., "Validation of the first and second components of the Heath-Carter modified somatotype method," Am. J. Phys. Anthrop., 3:? : $369-72,1970$. 